\title{
The Popular Base of Ukrainian Nationalism in 1917
}

In 1917, Ukrainian nationalists took advantage of the deterioration of central authority in the Russian Empire to make a bid for Ukrainian self-determination. The struggle for Ukrainian statehood continued under three successive national governments until 1920. The first year of the revolution, however, is crucial to understanding the evolution of the national movement in the Ukraine. In 1917, the Ukraine was as free of Russian interference and military occupation as it would be during the era of revolution and civil war. Ukrainian institutions and parties developed in freedom, democratic elections exposed the Ukrainian masses to nationalist agitation and measured their response, and the Russian government was forced to deal with the Ukraine as a distinct political entity.

The personalities, programs, and negotiations of the Ukrainian national governments have been extensively discussed in the literature on the Ukrainian revolution. ${ }^{1}$ By contrast, the popular base of the national movement has received less comprehensive treatment, even though the response of the Ukrainian masses to the national cause in 1917 is equally important for explicating the course of the Ukrainian revolution. In this paper, I will attempt to characterize the popular response by examining 1917 election returns in light of the social and economic conditions prevailing in the Ukraine. In particular, I will try to identify the social elements which supported the national movement along with the motives and intensity of their support. I will conclude with some observations concerning the extent to which the fate of the Ukrainian revolution was attributable to the nature of its popular base.

1. The best treatment in English on the Ukrainian national governments remains John S. Reshetar, The Ukrainian Revolution, 1917-1920 (Princeton, 1952). See also Oleh S. Pidhainy, The Formation of the Ukrainian Republic (New York, 1966). Analyses of Bolshevik policy toward Ukrainian nationalism include: Arthur E. Adams, Bolsheviks in the Ukraine (New Haven, 1963); Jurij Borys, The Russian Communist Party and the Sovietization of the Ukraine (Stockholm, 1960); and Richard Pipes, The Formation of the Soviet Union (New York, 1968). A comprehensive discussion of the Ukrainian S.R.'s in general and the UPSR Left in particular is presented in Iwan Majstrenko, Borot'bism: A Chapter in the History of Ukrainian Communism (New York, 1954). The most complete discussion of the revolution in Ukrainian is Dmytro Doroshenko, Istoriia Ukrainy, 1917-1923 rr., 2 vols. (New York, 1954). Doroshenko was a member of the liberal Ukrainian Socialist Federalist Party, and his interpretation, though not his selection of information, reflects an antisocialist bias. Pavlo Khrystiuk, Zamitky i materialy do istorii Ukrains'koi revoliutsii, 19171920 rr., 4 vols. (Vienna, 1921; reprint ed., New York, 1969) is valuable both for its Ukrainian populist view of the revolution and the extensive quotes from newspapers, minutes of congresses, and so forth, which are included in the notes. In Russian, see S. M. Korolivskii, M. A. Rubach, and N. I. Suprunenko, Pobeda sovetskoi vlasti na Ukraine (Moscow, 1967). Among the memoir literature, Mykola Kovalevs'kyi, Pry dzherelakh borot'by (Innsbruck, 1960 ) is very useful on the prerevolutionary roots of Ukrainian populism and the UPSR in the revolution. For observations of the head of the Rada government, see V. Vynnychenko, Vidrozhennia natsii, 3 vols. (Vienna, 1920). 
At the time of the February revolution, the prospects for an outpouring of national sentiment from the Ukrainian village seemed remote. Before 1917, the autocracy had rejected the very notion of a separate Ukrainian nationality and had vigorously repressed attempts by the Ukrainian intelligentsia to instill national consciousness among the peasantry. A ban on Ukrainian-language publications was enforced before 1905 . The revolutionary years $1905-7$ witnessed a flurry of Ukrainian-language periodicals, most of which had succumbed to official reaction and financial failure by $1908 .^{2}$ The small Ukrainian press which survived faced the constant threat of suppression if there was any suspicion of a nationalist message. Instruction in the Ukrainian language was not permitted in the schools, even at the primary level, until 1917. The electoral law revision, which accompanied Stolypin's coup, effectively eliminated Ukrainian representation in the Third and Fourth Dumas Thus, in the decade before the revolution, Ukrainian nationalists were unable to use the schools, the press, or the State Duma as a forum for national education and agitation.

In 1917, Ukrainians were predominantly a peasant people. The Imperial Russian Census of 1897 indicated that 87 percent of Ukrainians gained their livelihood from farming; only 2.4 percent lived in towns with twenty thousand inhabitants or more, ${ }^{3}$ By 1926, 86 percent of Ukrainians were still agriculturalists, and 94 percent lived in communities with a population of less than twenty thousand. ${ }^{4}$ Social and economic conditions rendered the Ukrainian peasantry difficult material for political mobilization. The fact that most Ukrainians were dispersed among numerous small villages made it difficult for the small nationalist elite to reach and organize the bulk of its constituency. An inadequate school system and the prohibition of instruction in the Ukrainian language resulted in high illiteracy rates in the countryside. In 1897 only one-seventh of rural Ukrainians were literate, and by 1926 only two-fifths were. ${ }^{5}$ Illiteracy further limited the nationalists' accessibility to the peasantry via the popular press. Moreover, as peasants, the mass of Ukrainians had very limited resources-of money or matériel一to contribute to the support of the nationalist movement.

The ramifications for Ukrainian nationalism arising from its predominantly peasant base were not altogether negative. In the village, the Ukrainian peasant was not exposed to the intense Russianizing pressure which denationalized so many Ukrainians in the cities and industrial centers. The village remained the preserve of Ukrainian ethnicity ; 88 percent of the region's peasants were ethni-

2. Iurii Tyshchenko, Pershi naddniprians'ki ukrains'ki masovi politychni hazety (New York, 1952) ; V. Domanyts'kyi, "Ukrains'ka presa v 1906 r.," Ukraina, 1 (1907), part 2, pp. 48-65.

3. N. A. Troinitskii, ed., Pervaia vseobshchaia perepis' naseleniia rossiiskoi imperii 1897 g., 89 vols. (St. Petersburg, 1899-1905). The following volumes cover the Ukrainian provinces: vol. 8, Volhynia; vol. 13, Ekaterinoslav; vol. 16, Kiev; vol. 32, Podolia; vol. 33, Poltava; vol. 46, Kharkov; vol. 47, Kherson; and vol. 48, Chernigov; see tables 13 and 22 in each volume (hereafter this source will be cited as 1897 Census; when citing all of these eight volumes, only the appropriate table will be noted). While the continental districts of Taurida province were also ethnically Ukrainian, it has proven impossible to find sufficient information on these districts to merit inclusion of Taurida in the study.

4. Vsesoiuznaia perepis' naseleniia 1926 goda, 56 vols. (Moscow, 1928-33), vol. 28, table 1, and vols. 11-13, table 6 (hereafter cited as 1926 Census).

5. 1897 Census, table $15 ; 1926$ Census, vol. 11, table 6. 
cally Ukrainian, and 93 percent of all Ukrainians were krest'iane. ${ }^{6}$ The great mass of Ukrainians therefore possessed a common class identity which reinforced their linguocultural distinctiveness from the other nationalities which populated the region.

Class and ethnic cleavages were closely related in the Ukraine. Russians manned the oppressive bureaucracy and were heavily represented among the principal landowners. Poles dominated the pomeshchiki class in the right bank provinces of Kiev, Podolia, and Volhynia. Petty trade, commerce, and much of industry on the right bank were, controlled by Jews who were therefore the peasantry's most visible creditors. As a consequence, the ethnic and socioeconomic grievances of the Ukrainian peasant proved mutually reinforcing and provided the foundation for a political movement which combined nationalism with a populist social program.

Between April and November 1917, the Ukrainian Socialist Revolutionary Party (UPSR) was able to parlay the formula of populism and nationalism into a convincing victory in the Constituent Assembly election. At its First Congress in Kiev on April 4-5, 1917, the UPSR established itself as the party that was most radical on the national issue. The UPSR immediately called for nationalterritorial autonomy and for a Ukrainian Constituent Assembly capable of dealing with questions of Ukrainian self-government. The First Congress declared that it regarded any attempt to postpone the convocation of such an organ "as a continuation of the old imperial policy of oppression and domination."7

As in Great Russia, the motivating force for the revolution in the Ukraine was socioeconomic reform. The Ukrainian village was susceptible to agitation by the UPSR, because the major social issues commanding the attention of the peasantry could be readily forged into national issues as well. On the question of agrarian reform, the UPSR adopted the formula of nationalization, which involved the transfer of state, church, and pomeshchiki holdings to a Ukrainian land reserve. The land would then be distributed to the peasants on the basis of a land norm through the intermediary of local land committees. ${ }^{8}$

The essential feature of the UPSR's position on land reform was its acceptance of individual farming. Neither Ukrainian S.R.'s nor Ukrainian peasants shared their Russian counterparts' attachment to communalism. The prevalence of hereditary plots and the weakness of the commune in the Ukraine fostered a strong proprietary attitude among the peasantry. Moreover, the proportion of middle and prosperous peasants in the village population was one of the highest in European Russia. ${ }^{9}$ Any serious attempt to enforce communal ownership or equalization of holdings was bound to generate stiff resistance among the Ukrainian peasantry.

6. 1897 Census, table 24. The vast majority of non-Ukrainian peasants were concentrated in border zones: Poles and Germans on the border with Austria-Hungary, Rumanians adjacent to Bessarabia, and Russians in eastern Ekaterinoslav and Kharkov provinces.

7. Majstrenko, Borot'bism, p. 38.

8. Pidhainy, Formation of the Ukrainian Republic, pp. 28, 54-55; Khrystiuk, Zamitky i materialy, 1:36-37.

9. In $1905,96.5$ percent of the households on the right bank, 82.1 percent of those in Poltava, and 68 percent in the Ukrainian districts of Chernigov held their allotments in hereditary household tenure. By contrast, communal tenure was nearly universal in the central Great Russian provinces. In Ukrainian provinces where communal tenure existed, the institu- 
The Ukrainian S.R.'s sought to saddle Russian Socialists' land programs with collectivist connotations. In this effort the UPSR was aided by the Marxist rhetoric of the Social Democrats and the Socialist Revolutionary Party's (PSR) infatuation with the obshchina. The head of the UPSR, Mykola Kovalevs'kyi, noted the success with which this issue could be turned against the Russians:

The Russians want to foist upon you, I said to the peasants, the socialization of land, that is, to transfer ownership of land to individual village communities and to abolish in this way your farms; you will no longer be masters of your own land, but will be workers on community land. The argument that Russian socialists "want to boil peasants in the capitalist cauldron," that is, to deprive them of independent status as proprietors and to transform them into proletarians, had special strength. Along with this I cited Karl Marx, Plekhanov, and even Lenin. With this "capitalist cauldron" I created a terrifying image of the future regime of the Ukraine, when Russian socialists would have succeeded in realizing their program not only in Russia but also in the Ukraine. ${ }^{10}$

Victor Chernov acknowledged the concern that fear of a communalistic land reform was separating Ukrainian peasants from the Russian S.R.'s. ${ }^{11}$ The desire to gain local control over land reform so that it would be carried out in a manner consistent with Ukrainian conditions was a powerful factor in generating national sentiment in the village.

The Ukrainianization of schools and public administration provided another issue which was readily adaptable to nationalist agitation. For the Ukrainian peasant the social inequities arising from his class position were compounded by discrimination against his language. ${ }^{X}$ The demand for the introduction of the Ukrainian language in primary schools, gymnasia, and local government was a universal feature of resolutions emanating from peasant organizations. The peasantry's previous experience with a centralized state dominated by Russians had not been happy. Nationalists emphasized that decentralization and national-territorial autonomy were the best guarantees of Ukrainianization. At the Kharkov Peasants' Congress in May, a UPSR delegate delivered this exhortation to the peasants:

Three hundred years ago we rose up against the pans, and took everything into our hands. We lived prosperously and free. Schools developed, the

tion was weak and the Stolypin reforms inaugurated a flood of separations. In 1905, 99 percent of the 271,000 households in Ekaterinoslav held their allotments communally; by 1914, 142,000 had separated their holdings into personal property. By 1914, communal tenure remained the norm only in Kharkov and Kherson provinces, and, even then, 100,000 households in each province had converted to hereditary holdings (see S. M. Dubrovskii, Stolypinskaia zemel'naia reforma [Moscow, 1963], pp. 572-73, 580-81; Statistika zemlevladeniia 1905 g., vol. 47: Chernigovskaia guberniia [St. Petersburg, 1906], table 4; and Korolivskii et al., Pobeda sovetskoi vlasti na Ukraine, pp. 47-48).

10. Kovalevs'kyi, Pry dzherelakh borot'by, p. 245. M. Iu. Shapoval (Revoliutsiinyi sotsializm na Ukrainy [Vienna, 1921], pp. 138-47) discusses the support of Ukrainian S.R.'s for small, inheritable private farms and their rejection of equalized, repartitional communes as reflected in the land reforms of the Central Rada and Directory. Shapoval was himself a member of the UPSR and chief architect of the Directory's land law.

11. Zemlia $i$ volia, May 24, 1917. 
Ukraine was an enlightened region, and from us learned people went to Muscovy. And what do we see now? Thirteen literates in a hundred people. We have not gone forward, but backward. The Ukraine needs Ukrainian schools, the Ukrainian language has to enter the middle schools and universities. Then the muzhik's tongue will become the nation's tongue. Each nationality has the right to its own schools. The Ukraine ought to govern itself, to conduct its own business with its own Rada in Kiev. ${ }^{12}$

The peasants in Kharkov and throughout the Ukraine responded to such appeals with demands of Ukrainianization and national autonomy within a federal Russian republic. ${ }^{13}$

Land reform, decentralization, and language policy furnished the issues, and the successful formation of the All-Ukrainian Peasants' Union (Selians'ka Spilka) supplied the transmission line for nationalist agitation. Established in early April as the economic-professional organization of the Ukrainian peasantry, Selians'ka Spilka assumed broad political influence in the national movement. The Spilka was organized into democratically elected village unions with counterparts at the volost, district, provincial, and all-Ukrainian levels. ${ }^{14}$ The organization convincingly maintained that it was the spokesman for the Ukrainian peasantry, and claimed many of the same quasiconstitutional rights as were claimed by the soviets in the cities. Ukrainian S.R.'s assumed an active role in the work of the Peasants' Union; and, in the course of 1917, the Spilka became the basic medium of UPSR influence in the village.

The newspapers of Selians'ka Spilka were widely circulated among the Ukrainian peasantry. The circulation of Narodnia volia the daily organ of the Peasants' Union and promoter of Ukrainian cooperation-grew from ten thousand to two hundred thousand copies within two months of the paper's appearance in March. ${ }^{15}$ The Spilka also published regional organs in Kiev, Poltava, Podolia, Chernigov, and Ekaterinoslav provinces, making it the largest publisher of Ukrainian newspapers and an excellent vehicle for conveying national ideals to the village. ${ }^{16}$

$X$ The strongest organizations of Selians'ka Spilka were located in Kiev and Poltava provinces, where Ukrainian populists built upon the vigorous village cooperative movement cultivated in the decade before the revolution. Many Ukrainian Socialists gained their contacts with the peasantry as well as with

12. Robitnycha hazeta, May 11, 1917. Throughout his speech, the UPSR delegate employed the term muzhits'ka (rather than the Ukrainian selians'ka, "peasant") to describe the lowly status to which Russian rule had reduced the Ukrainian language. Muzhits'ka was used by Russians to disparage the Ukrainian language, so that the speaker undoubtedly chose this term to further inflame his audience.

13. See Khrystiuk, Zamitky i materialy, 1:132-34. Other examples, by no means exhaustive, can be found in Robitnycha hazeta, April 12, April 14, and May 11, 1917; and Vlast' naroda, May 7, May 27, and June 15, 1917.

14. Khrystiuk, Zamitky i materialy, 1:137-38, n. 32.

15. The Ukrainian liberal daily Nova Rada and the USDRP organ Robitnycha hazeta each had circulations of about fifteen thousand (see Kovalevs'kyi, Pry dzherelakh borot'by, pp. 267-68). The Ukrainian daily Narodnia volia, published in Kiev, should not be confused with the Russian S.R. organ Volia naroda, which was printed in Petrograd.

16. Z. Kuzelia, $Z$ kul'turnoho zhyttia Ukrainy (Zal'tsvedel', 1918), p. 56; L. K. Il'inskii, Spisok pouremennykh izdanii za 1917 god (Petrograd, 1919), p. 185. 
other national activists through the cooperative movement of Kiev and Poltava ${ }^{17}$ and used these connections to facilitate the organization of Selians'ka Spilka and to expand its activities into the political sphere. The Poltava Provincial Congress of Selians'ka Spilka in April was the first regional peasant organization to demand that the Provisional Government recognize the rights of the Ukraine. ${ }^{18}$ In May, the Kiev Provincial Congress of Selians'ka Spilka added its voice by calling for Ukrainian autonomy, the creation of a Ukrainian sejm, and the Ukrainianization of the army. ${ }^{19}$

In the next few months, the Peasants' Union spread throughout the Ukraine. Pavlo Khrystiuk, a leading figure in the UPSR and Selians'ka Spilka, observed that
X
the organization of the peasantry proceeded more effectively where the peas- antry was more conscious and educated. In first place advanced Poltava province, behind it came Kiev province. The cause stood worst in Volhynia where the peasantry was benighted and downtrodden. It was difficult to organize the peasantry in those provinces where Russification had progressed deeply, and where, as in Kharkov and Ekaterinoslav provinces, the Russian Socialist Revolutionaries endeavored to conduct work on "all-Russian prin- ciples." But in these provinces and likewise in Volhynia as throughout the Ukraine the difficulties were overcome and all the peasantry finally joined the Ukrainian Peasants' Union. ${ }^{20}$

In June, the Chernigov Peasants' Congress, which had previously been affiliated with the All-Russian Peasants' Union, aligned with Selians'ka Spilka. ${ }^{21}$ The First All-Ukrainian Peasants' Congress, held in Kiev on June 6-10, attracted 2200 delegates from volost, district, and provincial peasant organizations and was dominated by Selians'ka Spilka delegates. The Congress assumed an aggressive stance in defense of Ukrainian national demands and the Central Rada. ${ }^{22}$

In October, the UPSR and Selians'ka Spilka gained influence among the Ukrainian peasants of Ekaterinoslav province. In the early months of the revolution, the Russian S.R.'s and the All-Russian Peasants' Union dominated peasant politics in this province. The rise of UPSR activity in Ekaterinoslav was followed by the Ukrainianization of the Peasants' Union in several districts and the expulsion of Russian S.R.'s from the new Spilkas. The tension between Ukrainian and Russian S.R.'s erupted at the Third Provincial Peasants' Congress in October, when the UPSR forced through a resolution sharply rejecting a bloc with the PSR in the coming election. The Constituent Assembly election was expected to be a test of strength pitting the Russian S.R.'s and Peasants' Soviets against the Ukrainian S.R.'s backed by Selians'ka Spilka. ${ }^{23}$

17. Kovalevs'kyi, Pry dzherelakh borot'by, pp. 101, 105, 200-21, 251-53. Kovalevs'kyi himself was a good example: before the revolution he worked in agricultural cooperation in Poltava; during the revolution he was editor of Narodnia volia and a member of the executive committees of the UPSR and Selians'ka Spilka.

18. Russkiia vedomosti, April 20, 1917.

19. Doroshenko, Istoriia Ukrainy, 1:75.

20. Khrystiuk, Zanitky $i$ materialy, 1:42-43.

21. Ibid., p. 43.

22. Doroshenko, Istoriia Ukrainy, $1: 83$.

23. Volia naroda, October 17, 1917; Robitnycha hazeta, October 14, 17, and 21, 1917. 
Table 1. Russian Constituent Assembly Returns, Ukrainian Provinces and Cities, 1917

\begin{tabular}{|c|c|c|c|c|c|c|c|c|}
\hline $\begin{array}{l}\text { Province } \\
\text { and City }\end{array}$ & $\begin{array}{c}\text { Ukrainian } \\
\text { Socialist }\end{array}$ & $\begin{array}{c}\text { UPSR/PSR } \\
\text { Bloc }\end{array}$ & Bolshevik & PSR & Kadet & $\begin{array}{c}\text { Jewish } \\
\text { Nationalist }\end{array}$ & Other & Total \\
\hline $\begin{array}{c}\text { Kiev } \\
\text { Kiev }\end{array}$ & $\begin{array}{r}1,256,271 \\
46,764\end{array}$ & & $\begin{array}{l}59,413 \\
32,576\end{array}$ & $\begin{array}{r}19,201 \\
8,358\end{array}$ & $\begin{array}{l}28,630 \\
18,742\end{array}$ & $\begin{array}{l}86,943^{a} \\
15,922\end{array}$ & $\begin{array}{r}177,269 \\
62,989 \mathrm{~b}\end{array}$ & $\begin{array}{r}1,627,727 \\
185,351\end{array}$ \\
\hline $\begin{array}{l}\text { Poltava } \\
\text { Poltava } \\
\text { Kremenchug }\end{array}$ & $\begin{array}{c}749,860^{c} \\
3,896 \\
5,395\end{array}$ & $\begin{array}{r}198,437 \\
5,654 \\
1,548\end{array}$ & $\begin{array}{r}64,460 \\
4,304 \\
5,266\end{array}$ & & $\begin{array}{r}18,105 \\
4,824 \\
1,758\end{array}$ & $\begin{array}{r}32,270 \\
4,404 \\
8,051\end{array}$ & $\begin{array}{r}86,124 \\
4,149 \\
2,973\end{array}$ & $\begin{array}{r}1,149,256 \\
27,231 \\
24,991\end{array}$ \\
\hline $\begin{array}{l}\text { Podoliad } \\
\text { Vinnitsa }\end{array}$ & $\begin{array}{r}656,116 \\
2,848\end{array}$ & & $\begin{array}{r}27,540 \\
3,058\end{array}$ & $\begin{array}{r}10,170 \\
562\end{array}$ & $\begin{array}{l}7,951 \\
1,420\end{array}$ & $\begin{array}{r}62,547 \\
3,227\end{array}$ & $\begin{array}{r}65,936 \\
3,146\end{array}$ & $\begin{array}{r}830,260 \\
14,261\end{array}$ \\
\hline $\begin{array}{l}\text { Volhynia } \\
\text { Zhitomir }\end{array}$ & $\begin{array}{r}569,044 \\
3,389 \mathrm{e}\end{array}$ & & $\begin{array}{r}35,612 \\
2,117\end{array}$ & $\begin{array}{r}27,575 \\
1,011\end{array}$ & $\begin{array}{r}22,397 \\
3,077\end{array}$ & $\begin{array}{c}55,967 \\
\ldots \ldots\end{array}$ & $\begin{array}{l}93,613 \\
11,030^{f}\end{array}$ & $\begin{array}{r}804,208 \\
20,264\end{array}$ \\
\hline $\begin{array}{l}\text { Ekaterinoslav } \\
\text { Ekaterinoslav } \\
\text { Lugansk }\end{array}$ & $\begin{array}{r}556,012 \\
12,950 \\
2,122\end{array}$ & & $\begin{array}{r}213,163 \\
20,849 \\
11,345\end{array}$ & $\begin{array}{r}231,717 \\
6,627 \\
2,003\end{array}$ & $\begin{array}{r}27,551 \\
9,244 \\
3,300\end{array}$ & $\begin{array}{r}37,032 \\
14,522 \\
\ldots \ldots\end{array}$ & $\begin{array}{c}127,574 \\
14,900 \\
4,881^{f}\end{array}$ & $\begin{array}{r}1,193,049 \\
79,092 \\
23,651\end{array}$ \\
\hline $\begin{array}{l}\text { Chernigov } \\
\text { Chernigovg }\end{array}$ & $\begin{array}{r}484,456 \\
1,148\end{array}$ & & $\begin{array}{r}271,174 \\
492\end{array}$ & $\begin{array}{r}105,565 \\
246\end{array}$ & $\begin{array}{r}28,864 \\
1,724\end{array}$ & $\begin{array}{r}28,308 \\
2,134\end{array}$ & $\begin{array}{r}56,379 \\
2,464\end{array}$ & $\begin{array}{r}974,746 \\
8,208\end{array}$ \\
\hline $\begin{array}{l}\text { Kherson }^{\mathbf{h}} \\
\text { Odessa } \\
\text { Nikolaev } \\
\text { Kherson } \\
\text { Elisavetgrad }\end{array}$ & $\begin{array}{r}114,000 \\
28,525 \\
4,105 \\
1,783 \\
4,640\end{array}$ & $\begin{array}{r}493,000 \\
12,510 \\
9,460 \\
4,090 \\
3,115\end{array}$ & $\begin{array}{r}95,000 \\
45,281 \\
11,500 \\
4,082 \\
3,214\end{array}$ & & $\begin{array}{r}59,000 \\
28,131 \\
6,046 \\
3,170 \\
4,136\end{array}$ & $\begin{array}{r}\dddot{77,784} \\
5,968 \\
5,524 \\
7,917\end{array}$ & $\begin{array}{c}171,000^{f} \\
21,300 \\
6,654 \\
3,452 \\
2,278\end{array}$ & $\begin{array}{r}932,000 \\
183,531 \\
43,733 \\
22,101 \\
25,300\end{array}$ \\
\hline $\begin{array}{l}\text { Kharkov } \\
\text { Kharkov }\end{array}$ & & $\begin{array}{r}795,558 \\
12,537\end{array}$ & $\begin{array}{r}114,743 \\
27,336\end{array}$ & $\begin{array}{r}42,331 \\
3,982\end{array}$ & $\begin{array}{l}58,302 \\
24,866\end{array}$ & $\ddot{5,303}$ & $\begin{array}{l}81,514^{f} \\
24,126\end{array}$ & $\begin{array}{r}1,092,448 \\
98,150\end{array}$ \\
\hline
\end{tabular}


Notes and Sources for Table 1:

a Provincial Jewish vote is incomplete.

b Includes 36,602 votes for List of Russian Voters.

c Includes USDRP vote as follows: province-22,613, Poltava (city) -2,117, Kremenchug 1,774 .

d Provincial returns may be incomplete.

e Includes a very small number of votes for Poalei Zion List.

I Includes Jewish vote.

B Does not include garrison vote. Some figures have been calculated from percentages in reports.

h Provincial returns are incomplete. Some figures calculated from percentages in reports. Ukrainian Socialist vote $=$ USDRP vote.

Sources: Calculations are based on information found in Oliver H. Radkey, The Election to the Russian Constituent Assembly in 1917 (Cambridge, Mass., 1950), pp. 78-80; and L. M. Spirin, Klassy $i$ partii v grazhdanskoi voine v Rossii (1917-1920 gg.) (Moscow, 1968), pp. 416-25, tables; and supplemented by the sources listed below. For provincial returns, see also M. Sobolev, "Vybory do vserossiis'kykh ta ukrains'kykh ustanovchykh zboriv na Poltavshchyni," Litopys revoliutsii, 1931, no. 3, pp. 48-49; and V. Shcherbakov, "Chernigovshchine nakanune revoliutsii v dooktiabr'skii period 1917 g.," Letopis' revolintsii, 1927, no. 2, pp. 64-65. City returns have been compiled primarily from newspaper reports. Kiev: Vlast' naroda, December 5, 1917; Poltava and Kremenchug: Sobolev, "Vybory," pp. 48-49; Vinnitsa: Robitnycha haseta, December 15, 1917; Zhitomir: Spirin, Klassy $i$ partii v grazhdanskoi voine $v$ Rossii, pp. 420-21; Ekaterinoslav: Bol'shevistskie organizatsii Ukrainy v period ustanovleniia $i$ ukrepleniia sovetskoi vlasti (noiabr' 1917-aprel' 1918 gg.) (Kiev, 1962), p. 227; Lugansk: Pravda, December 1, 1917; Chernigov: Russkiia vedomosti, December 2, 1917; Odessa, Nikolaev, Kherson and Elisavetgrad: Odesskiia novosti, November 17 and 23, 1917; Kharkov: Russkiia vedomosti, November 16, 1917. For a brief discussion of these sources, see note 24 .

The election to the Constituent Assembly in the Ukraine between November 12 and December 5, 1917 measured the success of the Ukrainian populists in linking the national and social questions in the political consciousness of the peasantry. ${ }^{24}$ As table 1 indicates, the Ukrainian populists scored a decisive electoral victory throughout most of the Ukraine.]

The strongest endorsement of Ukrainian populism came in Poltava province, where two UPSR lists gained 80.5 percent of the total vote and 83.2 percent of the vote outside the cities of Poltava and Kremenchug. ${ }^{25}$ The results indicated

24. The most complete discussion of the election can be found in Oliver H. Radkey, The Election to the Russian Constituent Assembly in 1917 (Cambridge, Mass., 1950), returns are on pp. 78-80. Somewhat less useful are the tables found in L. M. Spirin, Klassy $i$ partii $v$ grazhdanskoi voine $v$ Rossii (1917-1920 gg.) (Moscow, 1968), pp. 416-25. Spirin groups the non-Russian parties under the rubrics "Petty-Bourgeois Nationalist" and "Bourgeois Nationalist"; his totals can be used only in conjunction with other sources. For provincial returns, these primary sources should be supplemented by M. Sobolev, "Vybory do vserossiis'kykh ta ukrains'kykh ustanovchykh zboriv na Poltavshchyni," Litopys revoliutsii, 1931, no. 3, pp. 48-49; and V. Shcherbakov, "Chernigovshchine nakanune revoliutsii v dooktiabr'skii period 1917 g.," Letopis' revoliutsii, 1927, no. 2, pp. 64-65. City returns are compiled primarily from newspaper reports in late November and early December 1917 (see especially Vlast' naroda, Russkiia vedomosti, Pravda, Odesskiia novosti, and Robitnycha hazeta). Also see the sources given for table 1 .

25. The appearance of two lists reflected a split between the Spilka and the UPSR executive committee over the composition of a proposed joint list. The Spilka objected to the exclusion of peasant candidates in favor of party regulars and decided to advance a separate slate. Some UPSR luminaries, including Mykola Kovalevs'kyi, joined the dissident Selians'ka Spilka/UPSR list. The authorized UPSR ticket was joined by the very small 
that the UPSR and Selians'ka Spilka were the only nationalist groups which enjoyed significant support among the peasant masses of Poltava. The Ukrainian Social Democrats and liberal Socialist Federalists polled 2 percent and .8 percent of the ballots, respectively. The election also demonstrated the weakness of the Bolsheviks in the countryside, despite their recent promulgation of the radical land decree. The Bolsheviks gained only 5 percent of the vote outside of Kremenchug and Poltava.

Ukrainian nationalists also scored major victories in the provinces of the right bank, that is, in Kiev, Podolia, and Volhynia. In Kiev, the Ukrainian Socialist bloc of the UPSR, Selians'ka Spilka, and USDRP together received 77 percent of the provincial vote and over 83 percent of the vote outside the city of Kiev. A similar UPSR-dominated bloc obtained a 79 percent majority in Podolia. In Volhynia, the UPSR/Selians'ka Spilka list polled 71 percent. The Bolsheviks and the PSR each gathered less than 5 percent of the vote in all three provinces. The proportion of the vote which was cast for Ukrainian parties in each province very closely paralleled the proportion of Ukrainians in the population: in 1897, Ukrainians constituted 79 percent of the population in Kiev province ( 83 percent outside the city of Kiev), 81 percent in Podolia, 70 percent in Volhynia. $^{26}$ These facts suggest that there was extraordinarily little crossover among Ukrainian voters on the right bank to nonnationalist parties.

The four provinces of Poltava, Kiev, Podolia, and Volhynia were the core of Ukrainian nationalist strength in 1917. Although support for the Ukrainian populists was less substantial in Chernigov and Ekaterinoslav provinces, it was still significant. The UPSR/Selians'ka Spilka list in Chernigov received nearly one-half million votes -49.7 percent of the provincial total. In part this comparatively low percentage reflected the fact that the Russian-Ukrainian ethnic border passed through Chernigov and that the four northernmost districts had almost no Ukrainian population. ${ }^{27}$ Bolshevik and PSR strength was concentrated in the north while the Ukrainian S.R.'s gained a substantial victory in the southern uezdy. ${ }^{28}$ For example, in the southern district of Borzna the UPSR/Spilka ticket polled 49,480 votes ( 79.3 percent) versus 4000 votes for the Bolsheviks and under 2000 for the Russian S.R.'s. ${ }^{29}$ Nevertheless, Ukrainian peasants' support for the national parties was less monolithic in this region than on the right bank and in Poltava. The UPSR gained barely one-half of the vote in a province where Ukrainians comprised two-thirds of the population. The poorer showing of the Ukrainian populists in Chernigov may reflect the progress of Russification along the northern ethnic border. ${ }^{30}$

Left PSR organization of Poltava. Both Soviet and Western scholars have usually grouped the UPSR/PSR vote with the totals for the PSR. Unlike the other joint PSR/UPSR lists in Kharkov and Kherson, the Poltava ticket was dominated by the Ukrainians and has been grouped with the Ukrainian Socialist totals in the tables (see Sobolev, "Vybory," pp. 54-57).

26. 1897 Census, vols. $8,16,32$, table 13 .

27. 1897 Census, vol. 48 , table 13 .

28. Shcherbakov, "Chernigovshchine," pp. 63-65; D. Doroshenko, Moi spomyny pro nedavne-mynule (Munich, 1969), pp. 179, 211-12.

29. Volia naroda, December 9, 1917.

30. There was a substantial decline in the Ukrainian-speaking element along the ethnic border between 1897 and 1926. Russification is indicated by the fact that a significant minority of those who gave Ukrainian as their nationality in 1926 gave Russian as their native language (compare 1897 Census, vol. 48, table 13 and 1926 Census, vol. 11, table 6). 
The Ukrainian Socialist bloc (UPSR, Selians'ka Spilka, and USDRP) garnered 46.6 percent of the vote in Ekaterinoslav province, the Ukraine's most industrialized province containing a large population of Russian proletarians who voted overwhelmingly for the Bolsheviks.31 The Bolsheviks obtained 213,000 votes, or 18 percent of the provincial total. They were a minor factor in the village election, however: 80 percent of the Bolshevik total came from the Donbass (Bakhmut and Lugansk $u e z d y$ ) and the industrial cities of Ekaterinoslav, Iuzovka, Lugansk, Mariupol', and Amur-Nizhnedneprovsk. ${ }^{32}$

The village election in Ekaterinoslav remained a two-sided struggle between the UPSR and PSR. The Ukrainian Socialist bloc outpolled the Russian S.R.'s nearly two and one-half to one. In Pavlograd, an agricultural district in central Ekaterinoslav, the UPSR received 70 percent of the vote versus 18 percent for the PSR. ${ }^{33}$ Despite the late penetration of the local Peasants' Union by the Ukrainian S.R.'s and the longstanding activity of the PSR in Ekaterinoslav, by November the bulk of the peasantry had mobilized behind the Ukrainian populists.

The strength of Ukrainian peasant nationalism in Kharkov and Kherson provinces is more difficult to characterize on the basis of Constituent Assembly election returns. The Ukrainian populists did not advance separate slates in either province; instead, they formed blocs with the local PSR organizations, which were dominated by the pro-Ukrainian left wing. ${ }^{34}$ Specifically, Ukrainian populist organizations were not well entrenched in Kharkov and Kherson, where the development of the All-Ukrainian Peasants' Union was hindered by the extensive activity of the older PSR. In both provinces, peasant politics centered around the Soviets of Peasants' Deputies rather than Selians'ka Spilka. Neither Kharkov nor Kherson had a provincial Selians'ka Spilka newspaper. ${ }^{35}$

Despite the weaker conditions of Ukrainian organizations in Kharkov and Kherson, a significant part of the Left PSR/UPSR vote probably expressed the national as well as class sentiments of the peasantry. In May, the Kharkov Provincial Peasants' Congress voted for Ukrainian national-territorial autonomy in the face of considerable opposition from the Russian delegates, ${ }^{36}$ and the Kharkov peasants recognized the Rada as the competent authority in the Ukraine at their congress in August. ${ }^{37}$ In October, the Kherson Congress of Peasants' Deputies also insisted on the national-territorial principle for the Ukraine. ${ }^{38}$ The Left PSR/UPSR list was the only national ticket available to the Ukrainian peasantry in Kharkov. This slate gathered 72.8 percent of the provincial vote, the Bolsheviks 10.5 percent, and the Right Russian S.R.'s only 3.9 percent. In Kherson province, the joint PSR/UPSR ticket secured a 53 percent majority. 1926.

31. Ukrainians comprised 69 percent of the area's population in 1897 and 71 percent in

32. Calculated using I. K. Rybalka, "Rabochii klass Ukrainy na vyborakh vo vserossiiskoe i vseukrainskoe uchreditel'nye sobraniia," Istoriia SSSR, 1965, no. 1, pp. 114-25, and Utro Rossii, November 30, 1917.

33. Volia naroda, November 25, 1917.

34. Oliver H. Radkey, The Sickle Under the Hammer (New York, 1963), pp. 114, 116, 120-21, 296, 311-14.

35. Kuzelia, $Z$ kul'turnoho zhyttia Ukrainy, p. 56, and Il'inskii, Spisok, p. 185.

36. Volia naroda, May 7, 1917; Robitnycha hazeta, May 11, 1917.

37. Volia naroda, August 6, 1917.

38. Pobeda sovetskoi vlasti na Khersonshchine, 1917-1920 gg. (Kherson, 1957), p. 81. 
In addition, the Ukrainian Social Democrats ran one of their few separate lists in Kherson, and it received 12 percent of the vote. The USDRP did not enjoy substantial support in the village; of four rural districts for which results are available, the USDRP gathered 4-11 percent of the ballots. ${ }^{39}$ Yet despite the Ukrainian Social Democrats' weakness among the peasants, they outpolled the Bolsheviks over two to one outside the four major cities of Kherson province.

The Constituent Assembly election demonstrated that Ukrainian nationalism had a strong popular base in the Ukrainian village. In the eight provinces discussed above, 55 percent of all votes cast outside the Ukraine's ten largest cities went to lists dominated by the UPSR and Selians'ka Spilka; another 16 percent went to Left PSR/UPSR slates. Communist historians have sought to counter the evidence of Ukrainian nationalist strength in the village by emphasizing the peasantry's disaffection with the Rada in the fall of 1917. There are sufficient examples of peasant resolutions which condemned the "bourgeois politics" of the Rada to indicate widespread dissatisfaction with the Rada's prognostications on land reform and its generally moderate stance on socioeconomic issues. ${ }^{40}$ However, this discontent did not translate into rejection of the Ukrainian national cause. The government parties in the Rada, the USDRP, and liberal Socialist Federalists, fared badly among the peasantry in the election. The UPSR, which itself was increasingly critical of the social policies of the Rada, retained its influence in the village and overwhelmed the Bolsheviks in the election.

The peasant organizations which did repudiate the Rada at the end of 1917 demanded its recomposition into a truly "democratic"- that is, socialist-national parliament. They did not abandon the goal of self-determination. In this vein the peasants of Rybtsy in Poltava province declared in December:

We protest the counterrevolutionary work of the present composition of the Ukrainian Central Rada and declare the necessity to conduct reelections as quickly as possible, in order that the Rada, as the highest organ of selfdetermination, express our interests and not the interests of the counterrevolutionary bourgeoisie. ${ }^{41}$

In Kherson province, the village of Trikhaty concluded its protest against the Rada's interference in local affairs on behalf of the landowners as follows:

[We] as true Ukrainians stand on the side of all interests of the toiling people and social revolution, and we support the soviet power we have in the local area, and we will support it until the time when a Rada will be reelected which works in concert with the soviets and reflects the will of the toiling people. With all our strength and all the means we have available, we will

39. Russkiia vedomosti, November 26 and December 1, 1917.

40. The Sborniki dokumentov $i$ materialov issued by the various Ukrainian oblast committees on the fortieth and fiftieth anniversaries of the revolution contain numerous such denunciations of the Rada (see references in note 38 for examples). These collections are, of course, very selective and can be countered with the many expressions of peasant support for the Rada found in November and December 1917 issues of Robitnycha hazeta.

41. S. M. Korolivskii, ed., Velikaia oktiabr'skaia sotsialisticheskaia revoliutsiia na Ukraine, 3 vols. (Kiev, 1957), 1:215-16. 
Table 2. Ethnic Composition of the Ten Largest Ukrainian Cities, 1897

\begin{tabular}{lcccc}
\hline City & Population & \% Ukrainian & \% Russian & \% Jewish \\
\hline Odessa & 403,815 & 9.4 & 49.0 & 30.8 \\
Kiev & 247,723 & 22.2 & 54.2 & 12.1 \\
Kharkov & 173,989 & 25.9 & 63.2 & 5.7 \\
Ekaterinoslav & 112,839 & 15.8 & 41.8 & 35.4 \\
Nikolaev & 92,012 & 8.5 & 66.3 & 19.5 \\
Zhitomir & 65,895 & 13.9 & 25.7 & 46.4 \\
Kremenchug & 63,007 & 30.1 & 19.3 & 46.9 \\
Elisavetgrad & 61,488 & 23.6 & 34.6 & 37.8 \\
Kherson & 59,076 & 19.6 & 47.2 & 29.1 \\
Poltava & 53,703 & 56.0 & 20.6 & 19.9 \\
\hline
\end{tabular}

Source: N. A. Troinitskii, ed., Pervaia vseobshchaia perepis' naseleniia rossiiskoi imperii $1897 g_{.,} 89$ vols. (St. Petersburg, 1899-1905), vols. 8, 13, 16, 33, 47, and 48, table 13 in each volume.

struggle for the liberation of the Ukraine and for its national rights against all those who encroach on its rights and the sacred idea of the Revolution. ${ }^{42}$

The peasants were committed to the creation of a Ukraine which was both autonomous and socialist. They wanted land rights to be reserved for those who farmed the land with their own hands. They demanded the expropriation of nonpeasant proprietors-the pomeshchiki, state, church, and sugar refineries. Agrarian reform and indeed all local affairs were to be administered by village radas. Schools, administration, courts, and church were to be Ukrainianized. National autonomy was seen as the best guarantee that the socioeconomic reconstruction of the Ukraine would reflect local, not all-Russian conditions. The failure of the Bolsheviks to satisfy these desires with substantive programs left them isolated in the Ukrainian cities during the civil war.

Although the village proved receptive to the efforts of Ukrainian nationalists, cities and industrial centers were decidedly unfavorable territory for the national cause. As table 2 shows, urban centers were islands of non-Ukrainian language and culture throughout the Ukraine. By the time of the revolution, the situation of the Ukrainian nationality in the cities had not improved. In Kiev, the historical capital of the Ukraine and seat of the Central Rada, the proportion of Ukrainians actually declined to 16.4 percent in 1917 , with Russians constituting 49.5 percent of the population and Jews 18.7 percent. ${ }^{43}$ Poltava was the only provincial capital with a Ukrainian majority before the revolution.

In Kiev, nationalists' attempts to Ukrainianize the administrative, cultural, and educational institutions of the city were rebuffed at every turn by the Russian population. ${ }^{44}$ In the elections to the Kiev City Duma in late July, Ukrainians secured

42. Bor'ba za Velikii Oktiabr' na Nikolaevshchine, fevral' 1917 g.-mart 1918 g. (Nikolaev, 1957), pp. 215-16.

43. I. S. Bisk, $K$ voprosu o sotsial'nom sostave naseleniia $g$. Kieva (po dannym perepisi $1917 \mathrm{~g}$.) (Kiev, 1920). The census was conducted in September and covered the civilian population only. The test for nationality was self-identification; the Ukrainian percentage includes those identifying themselves as "Little Russians" ( 4.7 percent). In 1897, the civilian population was 21.3 percent Ukrainian.

44. Reshetar, The Ukrainian Revolution, pp. 136-38; Russkoe slovo, November 15, 1917; Russkiia vedomosti, December 8, 1917. 
Table 3. Results of Constituent Assembly Election, Major Ukrainian Cities, 1917 (in percent)

\begin{tabular}{lcccl}
\hline City & $\begin{array}{c}\text { Ukrainian } \\
\text { Parties }\end{array}$ & Bolsheviks & Kadets & $\begin{array}{c}\text { Other Major Lists } \\
\text { (over 10\%) }\end{array}$ \\
\hline Poltava & 38 & 16 & 18 & \\
Nikolaev & $31^{\mathrm{a}}$ & 26 & 14 & 14 (Zionists) \\
Elisavetgrad & $31^{\mathrm{a}}$ & 13 & 16 & 31 (Zionists) \\
Kremenchug & 29 & 21 & 7 & 22 (Zionists) \\
Kherson & $27^{\mathrm{a}}$ & 18 & 14 & 25 (Zionists) \\
Kiev & 25 & 18 & 10 & 20 (Russian Voters) \\
Odessa & $22^{\mathrm{a}}$ & 25 & 15 & 26 (Zionists) \\
Ekaterinoslav & 16 & 26 & 12 & 18 (Zionists) \\
Zhitomir & 16 & 10 & 15 & 40 (Jewish/Polish Nationalists \\
Kharkov & $13^{\mathrm{b}}$ & 28 & 25 & combined) \\
\hline
\end{tabular}

ancludes both USDRP list and joint UPSR/PSR list.

b Left PSR/UPSR list.

Sources: As for cities in table 1.

barely one-fifth of the seats. ${ }^{45}$ In Poltava, a Ukrainian deputy to the City Duma observed that "every kopeck for Ukrainian affairs, every trifle, had to be extracted from [the Duma] with a struggle." 46 These unfavorable conditions existed in the two cities with the strongest traditions of Ukrainian nationalism, where even before the Revolution large numbers of conscious, educated Ukrainians congregated and held positions of civic influence. In other major cities, such as Odessa, Kharkov, and Ekaterinoslav, local Ukrainian activists confined their efforts almost exclusively to cultural and educational work. Ukrainian influence in the politics of these towns depended upon the nationalistic spirit among the soldiers of the city garrisons. ${ }^{47}$ Table 3 indicates the proportion of Ukrainian votes in major cities in the Constituent Assembly election.

For a more precise picture of the weakness of Ukrainian nationalism in the towns, it is necessary to adjust some of the Ukrainian totals downward. A substantial part of the vote in urban areas was cast by the swollen military garrisons, ${ }^{48}$ which contained a large complement of peasant Ukrainian soldiers who were among the most nationalistic of their countrymen and consistently cast a high proportion of votes for Ukrainian Socialists. ${ }^{49}$ The presence of these soldiers could have been a favorable circumstance for the national cause during the revolution, because the soldiers helped to offset the weakness of Ukrainians in the

45. Russkiia vedomosti, July $26,1917$.

46. V. Andrievs'kyi, $Z$ mymuloho (1917 rik na Poltavshchyni), 2 vols. (New York, 1963), 1:110.

47. Doroshenko, Istoriia Ukrainy, 1:61-66; Volia naroda, June 6, 1917.

48. At the time of the February revolution, Odessa had a garrison of over fifty thousand troops; Kharkov had over forty thousand; Kiev and Nikolaev both had thirty-five thousand; Ekaterinoslav, twenty thousand; and Poltava, fifteen thousand. Smaller garrisons were found in nearly every town (see Korolivskii et al., Pobeda sovetskoi vlasti, p. 118).

49. The Third All-Ukrainian Military Congress, held October 21, 1917 in Kiev, was notable for its aggressively nationalistic resolutions. The Congress was attended by three thousand delegates, mainly Ukrainian S.R.'s, who were elected by nearly three million soldiers at the front and in the garrisons (see Pidhainy, Formation of the Ukrainian Republic, pp. 150-51, and Kievskaia mysl', October 21 and 22, 1917). 
Table 4. Garrison Vote in Constituent Assembly Election, Major Ukrainian Cities, 1917

\begin{tabular}{lccc}
\hline City & $\begin{array}{c}\text { Votes for } \\
\text { Ukrainians }\end{array}$ & $\begin{array}{c}\text { As \% of } \\
\text { Ukrainian Vote }\end{array}$ & $\begin{array}{c}\text { As \% of } \\
\text { Garrison Vote }\end{array}$ \\
\hline Kieva $^{\mathrm{a}}$ & 16,011 & 34 & 56 \\
Odessa & 14,629 & 36 & 38 \\
Kharkov & 5,795 & 46 & 36 \\
Ekaterinoslav & 3,770 & 29 & 42 \\
Elisavetgrad & 3,097 & 40 & 59 \\
Zhitomir & 1,786 & 53 & 36 \\
\hline
\end{tabular}

a Garrison total includes Ukrainian bloc and Bolsheviks only. Robitnycha hazeta, November 30,1917 , indicates that these two lists garnered 97 percent of the 5,100 votes that were cast in the first and second military precincts. See also notes for table 3.

Sources: Spirin, Klassy $i$ partii $v$ grazhdanskoi voine v Rossii, pp. 422-25; Oleh S. Pidhainy, The Formation of the Ukrainian Republic (New York, 1966), pp. 211-12; Odesskiia novosti, November 17 and 21, 1917.

civilian urban population. However, the Ukrainian peasant troops in the garrisons constituted a transitory force in the politics of the cities. War weariness stimulated a high desertion rate. The troops were also anxious to return to the villages in order to defend their interests during the spontaneous land reform being carried out by the peasantry. Consequently, the Ukrainian soldiers melted back quickly into the village, leaving the national cause in the cities in a more disadvantaged position than suggested by table 3 . Table 4 shows the Ukrainian share in the garrison vote of several major cities; table 5 reflects the party strength in the election adjusted to reflect the civilian vote only.

Ukrainian nationalists were outvoted in every city by at least one group which was apathetic or antipathetic toward the Ukrainian cause. Among civilian electors in Kiev, the Ukrainian bloc was defeated by the conservative List of Russian Voters led by the Ukrainophobe Vasilii Shulgin. In Odessa the Ukrainian nationalists were defeated by Zionists and Bolsheviks, in Kharkov by Kadets and Bolsheviks, and in Ekaterinoslav by Bolsheviks and Zionists.

Aggravating the general weakness of the Ukrainians in the cities was the lack of a strongly nationalistic Ukrainian proletariat. As the revolution drifted steadily leftward it became increasingly apparent that the political struggle in the towns and industrial centers would be settled among the workers. Yet the historical development of industry in the Ukraine had placed the nationalists at

Table 5. Civilian Vote in Constituent Assembly Election, Major Ukrainian Cities, 1917 (in percent)

\begin{tabular}{lcccc}
\hline City & $\begin{array}{c}\text { Ukrainian } \\
\text { Parties }\end{array}$ & Bolsheviks & Kadets & $\begin{array}{c}\text { Other Major Lists } \\
\text { (over 10\%) }\end{array}$ \\
\hline Elisavetgrad & 23 & 9 & 19 & 39 (Zionists) \\
Kiev & 20 & 13 & 12 & 29 (Russian Voters) \\
Odessa & 18 & 19 & 17 & 34 (Zionists) \\
Ekaterinoslav & 13 & 27 & 13 & 20 (Zionists) \\
Zhitomir & 10 & 9 & 14 & 49 (Poles and Jews) \\
Kharkov & 8 & 23 & 29 & 10 (Mensheviks) \\
\hline
\end{tabular}

Notes and Sources: As for tables 3 and 4. 
Table 6. Constituent Assembly Election Returns, Donbass Region, 1917

\begin{tabular}{lcccr}
\hline & Ukrainian & & & \\
& Socialists & Bolsheviks & PSR & Mensheviks \\
\hline City of Lugansk & 2,122 & 11,345 & 2,003 & 1,710 \\
Donbass Mines & 889 & 17,075 & 2,043 & 352 \\
Russian Society & 24 & 1,105 & 903 & 76 \\
Factory (Iuzovka) & & & & \\
\hline
\end{tabular}

Sources: Pravda, November 25 and December 1, 1917; Bol'shevistskie organizatsii Ukrainy, p. 339.

a decided disadvantage in this contest by failing to bring a substantial number of Ukrainians into the proletariat. As late as 1926 only 1.3 percent of Ukrainians were employed in factory-mill industries and railroad transport. ${ }^{\mathbf{5 0}}$ In $\mathbf{1 8 9 7}$, the workers in the Donbass were over two-thirds Russian and only one-fourth Ukrainian; by 1926, the Ukrainian proportion had risen to 35 percent. $^{51}$ The workers in the giant Briansk metallurgical factory in Ekaterinoslav were twothirds Russian, and in the machine construction enterprises of Kharkov they were 50 percent Russian, while Ukrainians were scarcely evident in the proletariat of Odessa and Nikolaev. ${ }^{52}$

The small ethnically Ukrainian proletariat was subject to intense Russianizing pressures. Russian culture and language dominated the major cities and industrial centers. The intellectuals who provided the leadership of the Social Democratic movement in the Ukraine were overwhelmingly Russian and Jewish. The extent to which Ukrainians were denationalized upon entering the industrial environment was revealed by the complaint of a Ukrainian Socialist, who noted in 1906 that "the Ukrainian proletariat has become so completely Russianized that members of the [Ukrainian Social Democratic Labor] Party working among them must first teach them the Ukrainian language." 53 Both legal and illegal literature distributed to Ukrainian workers before the revolution was invariably printed in the Russian language. The all-Russian orientation of the Social Democratic and workers' press was assured by the fact that most of it was imported from Moscow and St. Petersburg. ${ }^{\mathbf{5 4}}$

Ukrainian nationalists proved unable to overcome the obstacles which hindered their efforts to generate a specifically Ukrainian workers' movement. The Ukrainian Social Democratic Party lay dormant between 1907 and 1917, the victim of official repression and worker disinterest. At the time of its revival in March 1917, the USDRP was plagued by haphazard organization, extensive Russification among Ukrainian workers, and the antipathy of Russian social democracy toward the formation of a nationalistic Ukrainian wing. The UPSR was not organized until April 1917 and generally forswore agitation among the workers, considering it to be the preserve of the Social Democrats. ${ }^{55}$

50. 1926 Census, vol. 28 , table 1 .

51. 1897 Census, vol. 13, tables 21 and 22; 1926 Census, vol. 30, table 1.

52. Istoriia mist i sil Ukrains'koi RSR: Dnipropetrovs'ka oblast' (Kiev, 1969), p. 67; Kharkivs'ka oblast" (Kiev, 1967), pp. 74-75.

53. As quoted in Ralph Carter Elwood, Russian Social Democracy in the Underground: A Study of the RSDRP in the Ukraine, 1907-1914 (Assen, The Netherlands, 1974), p. 10.

54. Ibid., pp. 208-18.

55. Kovalevs'kyi, Pry dzherelakh borot'by, pp. 255-57. 
Table 7. Composition of Executive Committees of Workers' Soviets, Major Ukrainian Cities, November 1917-January 1918

\begin{tabular}{|c|c|c|c|c|}
\hline Soviet & Total & $\begin{array}{l}\text { UPSR/ } \\
\text { USDRP }\end{array}$ & Bolsheviks & $\begin{array}{c}\text { Other Russian } \\
\text { Socialists }\end{array}$ \\
\hline Nikolaev ${ }^{\mathfrak{a}}$ & 120 & 11 & 37 & 56 \\
\hline Odessa & 70 & 6 & 28 & 25 \\
\hline Elisavetgrad ${ }^{a}$ & 40 & 11 & 8 & 14 \\
\hline Kharkov & 40 & 4 & 19 & 15 \\
\hline Enakievo (Donbass)a & 40 & 0 & 31 & 9 \\
\hline Kiev & 30 & 2 & 18 & 10 \\
\hline Kremenchuga & 15 & 1 & 9 & 5 \\
\hline
\end{tabular}

a Workers' and Soldiers' Soviet. As the previous discussion indicated, inclusion of soldiers would have overrepresented rather than underrepresented Ukrainians.

Sources: Kiev: Bol'shevistskie organizatsii Ukrainy, p. 437; P. I. Garchev, "Sostav odesskogo soveta rabochikh deputatov v 1917-1918 gg.," Istoriia SSSR, 1968, no. 5, p. 114; Kharkov and Kremenchug: Rady Ukrainy $v 1917$ r., pp. 246, 253 note; A. Aleshin, "K istorii bor'by za Oktiabr' na Nikolaevshchine," Letopis' revoliutsii, 1928, no. 3, p. 115; Elisavetgrad: S. K. Mel'nyk, Peremoha radians'koi vlady na Pivdni Ukrainy (berezen' 1917-berezen' 1918 $r r$.) (Kiev, 1966), p. 162; Enakievo: A. I. Smolinchuk, Bol'sheviki Ukrainy v bor'be za sovety (mart 1917-ianvar' 1918 gg.) (Lwów, 1969), p. 189.

As a consequence of these factors, much of the Ukrainian proletariat was co-opted by the Russian Socialists. In the election to the Constituent Assembly the strength of the Ukrainian Socialists among the industrial working class fell far below the share of ethnic Ukrainians in the labor force. The Donbass is one of the few areas where it has been possible to present the workers' vote in relative isolation; returns from some representative precincts are presented in table 6. Although Ukrainians comprised about one-third of the miners and metallurgical workers in the Donbass, Ukrainian Socialists polled less than one-tenth of the vote in this region.

The elections to the executive committees of the workers' soviets at the end of 1917 provide a more comprehensive picture of the weakness of the Ukrainian Socialists among the proletariat. The manner in which the executive committees were chosen ensured that their composition would closely reflect the political sentiments of the workers. General deputies to the soviets were elected at the factory level and made subject to recall. The general deputies, several hundred strong in the major soviets, in turn elected the executive committee. Deputies voted for lists submitted by individual parties or blocs; seats were then assigned on a strict proportional basis. ${ }^{56}$ The results in several soviets are presented in table 7.

The results of the elections to the Constituent Assembly and workers' soviets demonstrated that the Ukrainian Socialists were virtually without working-class support. The dominance of Russian Socialist influence among the proletariat posed a serious threat to Ukrainian nationalism. In 1917, many soviets paid lip service to the concept of Ukrainian self-determination; their commitment, however, was more ideological than practical. The Russian leadership of the soviets

56. See Oskar Anweiler, The Soviets: The Russian Workers, Peasants and Soldiers Councils, 1905-1921 (New York, 1974); on the Ukraine specifically, see Iu. M. Hamrets'kyi, Zh. P. Tymchenko, and O. I. Shchus', Rady Ukrainy v 1917 r. (Kiev, 1974). 
made the soviets suspect as centralizing forces and the Ukrainian Socialists were mindful of the danger presented by the workers' soviets. The attachment of the Left S.R.'s to the slogan "All Power to the Soviets" became the major stumbling block to a Ukrainian-wide alliance between the UPSR and the Left PSR.57 When the revolutionary principle of self-determination of peoples clashed with national and class self-interest, the non-Ukrainian soviets became centers of Bolshevik support in the Ukraine. Ukrainian nationalists were unable to mobilize a working-class constituency and thereby lost access to industrial resources and transport facilities.

The results of the Constituent Assembly election repudiate the notion that the Ukrainian peasantry lacked national consciousness in 1917. The barriers to the spread of the Ukrainian national idea to the village, which were erected by the autocracy, created the impression that the national movement lacked a popular base. However, peasants' economic grievances against non-Ukrainians and discrimination against the Ukrainian language provided the issues upon which national consciousness among the peasantry could be politicized. The speed with which the UPSR generated support in 1917 demonstrated that the Ukrainian peasants formed a natural and distinct constituency. Lenin noted the victory of the Ukrainian populists in the Constituent Assembly election and chastised "some comrades" for not realizing the implications of this victory:

Under these circumstances, to ignore the importance of the national question in the Ukraine-a sin of which Great Russians are often guilty (and of which Jews are guilty perhaps only a little less often than the Great Russians) - is a great and dangerous mistake. The division between the Russian and Ukrainian Socialist Revolutionaries as early as 1917 could not have been accidental. ${ }^{58}$

The elections also demonstrated that Ukrainian nationalism as a substantial political force was a one-class movement. Ukrainians were poorly represented among the urban bourgeoisie and proletariat; moreover, these classes were the most Russianized segments of Ukrainian society. Many Ukrainians in the cities and industrial centers gravitated to the appropriate all-Russian class partiesthe Kadets or Russian Social Democrats. Ukrainian intellectuals did supply the leadership cadres of the national parties; but the Ukrainian bourgeoisie was numerically too weak to sustain its own class-oriented movement, as illustrated by the extraordinarily poor showing of the Ukrainian Socialist Federalist Party in the elections. In the radical climate of 1917 , the weakness of the Ukrainian movement among the proletariat proved even more crucial. It provided the Bolsheviks with their entering wedge into the Ukraine. The Donbass and the great industrial cities became the base of support for the Bolsheviks in their struggle with the Ukrainian national Socialists.

57. Radkey, The Sickle Under the Hammer, pp. 311-14.

58. V. I. Lenin, "The Constituent Assembly Elections and the Dictatorship of the Proletariat" (December 1919), in V. I. Lenin, Collected Works, vol. 30 (Moscow, 1965), pp. 270-71. In Russian, see V. I. Lenin, Polnoe sobranie sochinenii, 5th ed., vol. 40 (Moscow, 1963), p. 19. 
Social conditions in the Ukraine provided only one realistic orientation for the nationalist cause in 1917-agrarian populism. The Ukrainian peasantry, roused to political consciousness by the revolution, was the single greatest asset of the national movement. As a constituency, however, the peasants also saddled the national movement with organizational and material liabilities. They formed a massive constituency which was difficult to organize and coordinate over the wide territory of the Ukraine. In addition, the Ukrainian village was unable to provide many of the material resources necessary to sustain the cause. The obstacles to the development of the Ukrainian revolution became nearly insurmountable because of the inability of Ukrainians to control the major cities and industrial centers. Opponents of Ukrainian national aspirations were consistently successful in denying Ukrainians access to the facilities necessary to integrate and supply an all-Ukrainian national effort. The Ukrainian revolution failed not through the lack of a popular base, but through the organizational problems and resource deficiencies arising from its overwhelmingly peasant constituency. 